\title{
Notes Toward an Understanding of the U.S. Market in Foreign LL.M. Students: From the British Empire and the Inns of Court to the U.S. LL.M.
}

Bryant G. Garth

University of California - Irvine, bgarth@law.uci.edu

Follow this and additional works at: https://www.repository.law.indiana.edu/ijgls

Part of the International Law Commons, Legal Education Commons, and the Legal Profession

Commons

\section{Recommended Citation}

Garth, Bryant G. (2015) "Notes Toward an Understanding of the U.S. Market in Foreign LL.M. Students:

From the British Empire and the Inns of Court to the U.S. LL.M.," Indiana Journal of Global Legal Studies:

Vol. 22 : Iss. 1 , Article 3.

Available at: https://www.repository.law.indiana.edu/ijgls/vol22/iss1/3

This Article is brought to you for free and open access by the Law School Journals at Digital Repository @ Maurer Law. It has been accepted for inclusion in Indiana Journal of Global Legal Studies by an authorized editor of Digital Repository @ Maurer Law. For more information, please contact rvaughan@indiana.edu.

\section{$\Psi$}

JEROME HALL LAW LIBRARY

INDIANa UNIVERSITY

Maurer School of Law
Bloomineton 


\title{
Notes Toward an Understanding of the U.S. Market in Foreign LL.M. Students: From the British Empire and the Inns of Court to the U.S. LL.M.
}

\author{
BRYANT G. GARTH*
}

Mindie Lazarus-Black and Julie Globokar's article on "Foreign Attorneys in U.S. LL.M. Programs: Who's In, Who's Out, and Who They Are" uses interviews, LL.M. student observations, and actual admissions committee documents from one Midwest and one East Coast law school to confirm the tremendous growth of those programs over the past two decades in the United States and indicate who makes the journey to the United States; how foreign LL.M. candidates pitch themselves to admissions committees; how those admissions committees evaluate candidates; and what candidates expect from LL.M. programs. The voices that come through are quite compelling. We now know more about this aspect of the "internationalization" of legal practice. The authors situate their research in the literature on audit cultures and issues of commensuration, explaining how these practices affect what individuals put into their applications and how admissions committees assess those applications. Those contributions make for interesting reading as well as strong scholarly findings. My contribution to this symposium, however, will take a somewhat different perspective, and will place the findings into a framework that differs substantially from, but is not necessarily inconsistent with, Lazarus-Black and Globokar's. ${ }^{1}$

Globalization, including educational exchange in law, must be situated within a long history of competition among nations for global hegemony. Law has long been an instrument and point of entry into this imperial competition. One way was for the "civilized nations" to use international law to legitimate their dominance, moderate the behavior of these nations among themselves, and give them a claim of legitimacy

* Chancellor's Professor of Law, University of California-Irvine.

1. This perspective draws on work over the past several decades with my collaborator Yves Dezalay. The most recent book is Yves DEZALAY \& BRYANT G. GARTH, ASIAN LEGAL REVIVALS: LAWYERS IN THE SHADOW OF EMPIRE (2010).

Indiana Journal of Global Legal Studies Vol. 22 \#1 (Winter 2015) (C) Indiana University Maurer School of Law 
when attacking those nations outside the civilized order-including, at times, China and Turkey, for example. ${ }^{2}$ The pressure on Japan and China to emulate European legal systems late in the nineteenth century came in part from an effort to gain access to the benefits of being "civilized." Considerable educational exchange between Asia and the West, including exchange with Germany and the United States, was part of that process. ${ }^{3}$

The second way was a central component of empire itself. In the classic situation well exemplified by India, ${ }^{4}$ the colonial power, in this case Great Britain, sought to legitimate its rule at home and in India by building a legal system in India-thereby claiming to civilize the Indians by teaching them governance. ${ }^{5}$ As part of the process, they educated Indians-notably in law-who could also help rule according to British colonial law. The British self-consciously made sure that they educated Indian elites, particularly Brahmins and Parsis from Bombay, and some of the children of merchants also paid their own way to the Inns of Court via Oxford or Cambridge. The Indian elite was in this way co-opted into the colonial system and also came to identify with British values, including the value of the British common law. In a famous statement by Tomas Babington Macaulay, the goal was to create "a class who may be interpreters between us and the millions whom we govern; a class of persons, Indian in blood and colour, but English in taste, in opinions, in morals, and in intellect." 6

At the same time, these elites used their British education to reinforce their social status within India. ${ }^{7}$ Even though they identified with British values, they became the leaders of independence. Often they came to favor independence in part by experiencing second-class treatment in Britain while they were studying. The leadership of the Congress Party, including Jawaharlal Nehru, the first Prime Minister, came from this process, and of course, Mahatma Gandhi was a lawyer (although his route to Indian leadership was unique). Nehru and the

2. See MARK MAZOWER, GOVERNING THE WORLD 71 (2012).

3. See generally Zhenmin Wang, Legal Education in Contemporary China, 36 INT'L LAW. 1203 (2002); Malcolm M. Feeley \& Setsuo Miyazawa, The State, Civil Society, and the Legal Complex in Japan, in Fighting For Political Freedom: COMPARATIVe StUdies of the Legal Complex AND Political Liberalism 151 (Terence C. Halliday, Lucien Karpik \& Malcolm M. Feeley eds., 2007).

4. See generally Mitra Sharafi, LaW AND IDEnTtTy in Colonial South ASIA: PARSI LEGAL CULTURE, 1772-1947 (2014) (explaining how colonial power and British rule shaped the Parsi legal system).

5. DeZalay \& GaRTh, supra note 1 , at 38-40, 65-73.

6. Niall Ferguson, EmPIRE: How Britain MAde the Modern World 190 (Penguin Books 2004).

7. DEZALAY \& GARTH, supra note 1 , at 38-40, 65-73. 
Congress Party created a government that sought to preserve the values of British law.

Elements of this process of mutual co-optation within a global and national hierarchy can be found not just among the British colonies, but also the Dutch in Indonesia; the Spanish and Portuguese in Latin America (where "civilized" nations used law to justify rule over indigenous groups); 8 and the United States in the Philippines (where William Howard Taft, the first governor, sought to build up gentlemen lawyers). ${ }^{9}$ One result of this mutual co-optation process, again best represented by the British ex-colonies, was that when a particularly important case came up, British authority had more value than local authority. Indeed, in Singapore and Hong Kong in particular, British Queen's Counsels would fly in to argue the case well after formal independence. ${ }^{10}$

Finally, a third way law played a role was in the competition among empires. Credibility for the "universals," including law, of any one colonial power potentially strengthened its global position. Educational exchange was central to that process. There is evidence, for example, that the Dutch change in policy toward educating Javanese aristocrats early in the twentieth century was in part a product of competition with the British. ${ }^{11}$ There is no question that both the British, and later the Americans, claimed global superiority because, unlike their competitors, the British and the Americans insisted on governing their colonies by the rule of law and on improving the ability of colonial citizens to govern themselves.

My basic observation is that the U.S. LL.M. for foreign law graduates is best understood as part of an imperial process that has much in common with what the European imperial powers pursuedwith the notable difference that the process operates now through educational markets, not colonial governance. Before proceeding, I want to point out that my purpose is not to denounce imperial processes. The word imperial may put off some readers, especially given that the operation of the market is evident today (students choose to attend and have many choices), but the point here is to explain sociologically what the patterns of import and export are and how they relate to larger

8. See generally Rogelio PÉREZ-PERDOMO, LATIN AMERICAN LAWYERS: A HISTORICAL INTRODUCTION (2006); Martin Böhmer, Legal Education Reform: How the Academy at Chuquisaca Forged Argentina's Founding Elite, 63 J. LEGAL EDUC. 373 (2014) (explaining the relation of legal education and leadership in the Latin American colonies with the Spanish governance).

9. DEZALAY \& GARTH, supra note 1, at 55-57.

10. Id. at 144 .

11. Id. at 41-44 (noting the parallels in time and in the intellectual movements in Europe). 
questions of hierarchy and international political economy. The flow of people and expertise is a key aspect of international political economy, competition among states, and elite reproduction.

Lazarus-Black and Globokar frame their article differently. The findings, according to one reading of the article, might be used to make a positive case for globalization as an extension of the American dream. "Internationalization" or globalization according to this perspective means that individuals from all over the world are seeking a U.S. law degree and to emulate the more prestigious role of the U.S. lawyermaking social change and problem solving at the highest levels. The interviews operate within this framework. Access to the rewards of a U.S. legal education, the authors suggest, is not limited to well-to-do students. ${ }^{12}$ Even though the costs are high and scholarships rare, families and individuals are managing to make their way to these graduate LL.M. programs. Their stories are often inspiring. Further, the interviews with admissions officials suggest that, from the U.S. side, it is not only about enhancing tuition revenues. The expansion of the LL.M. programs admittedly seems to stem from a motivation to enhance revenue, but there are limits on this move for expansion. Graduate LL.M. programs are not just cash cows; they raise concerns about supporting the students, for example, and not clashing with the faculty teaching courses that LL.M.s would like to take. ${ }^{13}$

Consistent with this reading, the authors conclude, "[O]ur research suggests we are witnessing a process of inclusion in both legal education and the legal profession more generally of persons who were previously denied access to its ranks." 14 The second major conclusion is also consistent with this reading. Law schools are "important sites . . . to examine the content, structures, and processes of globalization." 15 The "transnationalization of legal education" is a key part of that process. ${ }^{16}$ The idea, which is consistent with their data, is that the internationalized legal profession, led by the United States, is opening up to ambitious and hardworking individuals from around the globe.

The article also contains important insights about hierarchy, which complicate the "access" to the international "know-how" part of the story. The "story of lack" in the admission essays is particularly compelling. The foreign students explain in their essays what is

12. Mindie Lazarus-Black \& Julie Globokar, Foreign Attorneys in U.S. LL.M. Programs: Who's In, Who's Out, and Who They Are, 22 InD. J. Global LeGaL STUD. 3, 16 17 (2015).

13. Id. at 26 .

14. Id. at $\mathrm{b} 2$.

15. $I d$. at 63 .

16. Id. at 64 . 
supposedly wrong or missing in their own societies and legal systems and make the case for access to the modern or better functioning technologies and doctrines coming from the United States. ${ }^{17}$ The authors point out that the "genre" of personal statements in this manner responds to "dominant power structures." 18 One comment quoted in the text also stands out: "[W]e . . . are not Harvard," points out the admissions official from the midwestern law school. ${ }^{19}$ Finally, there is the hierarchy of achievement, with faculty complaining that foreign students are often not "up to par" or are "just very quiet," which inhibits in-class discussion and engagement. ${ }^{20}$ Nevertheless, the authors work more with the "access" story than the story of hierarchy. They are careful to say that not all the LL.M. students are privileged, for example, which is meant to debunk the idea that the globalization of legal education favors the advantaged (as it did with the European colonial processes).

Instead of -or in addition to-focusing on the access issues and the emergence of transnational legal education as a concomitant of globalization, I would frame today's globalization in relation to the imperial relationships that have long been central to law and legal education. What is different from the colonialism in India and elsewhere, until independence and after World War II, is that the U.S. approach to global influence is rather market oriented. The United States extends its influence and hegemony more from the export of its governing expertise - law but also economics in particular-as universal and modern. ${ }^{21}$ The export of economics as a governing expertise was characteristic of the Cold War as a way to influence mostly authoritarian governments to open their markets while serving as allies against communism. Well-known examples include the "Chicago boys" in Chile ${ }^{22}$ and the "Berkeley Mafia" in Indonesia, ${ }^{23}$ but the same process with economics is evident in South Korea, India, and elsewhere. ${ }^{24}$ There

17. Id. at $37-38$.

18. Id. at 32 (citing William F. HaNks, LaNGUAGE AND CoMmUniCaTive PRACTices (1996)).

19. Id. at 22 .

20. Id. at 28 .

21. See generally Yves Dezalay \& BRYANT G. GaRTH, THE INTERnationalization of PALACE WARS: LAWYERS, ECONOMISTS, AND THE CONTEST TO TRANSFORM LATIN AMERICAN STATES (2002).

22. Id. at 113 (discussing Chilean economists funded by U.S. organizations to study at the University of Chicago and who returned to serve Pinochet's authoritarian government and its turn to neoliberal economic policies).

23. DEZALAY \& GARTH, supra note 1, at 120-25 (Indonesian economists trained at Berkeley who worked with Suharto's authoritarian government to open the Indonesian economy to trade and investment).

24. Id. at $125-31,157-62$. 
were also efforts by the Ford Foundation and U.S. AID in the 1960 s and 1970s to export the U.S. approach to legal education, but the efforts were not successful-at least in the short term. ${ }^{25}$ At that time, moreover, the market for legal expertise was not at all global. The export of U.S. economics, in contrast, further globalized economics and placed U.S. economics departments at the center of that marketpaving the way for the spread of neoliberal economics. ${ }^{26}$

The earlier imperial patterns remained despite the end of colonial rule. Ambitious law graduates in South America, for example, would gain credibility and prestige at home through degrees from civil law countries; mainly France, Portugal, and Spain, but not through degrees from common law countries like the United States. ${ }^{27}$ As we have detailed in our book on Latin America, the market shifted in the 1970s and $1980 \mathrm{~s} .{ }^{28}$ The rise of U.S. style corporate law, often associated with U.S. investment after World War II, the debt crisis in the 1970s and 1980 s, and the subsequent move toward privatization, built up an interest in U.S. legal education since other countries were ill-suited to train corporate lawyers modeled on those in the United States. ${ }^{29}$ Then, toward the end of the Cold War, the development of human rights law and human rights advocacy organizations further shifted the hierarchy of legal education abroad toward the United States. ${ }^{30}$ U.S. graduate law degrees-above all the LL.M.--became central both for elite corporate lawyers from outside the United States and for lawyers in human rights and other activist organizations.

The growth of transnational law under strong U.S. influence-in intellectual property, international trade via the World Trade

25. See generally JAMES GARDNER, LEGAL IMPERIALISM: AMERICAN LAWYERS AND FOREIGN AID IN LATIN AMERICA 239-81 (1980) (explaining the failure in exporting the U.S. approach to legal education to Latin America); David M. Trubek \& Marc Galanter, Scholars in Self-Estrangement: Some Reflections on the Crisis in Law and Development Studies in the United States, 1974 WIS. L. REV. 1062 (providing an analysis of why law and development efforts, in particular, to reform legal education, were unsuccessful); Jayanth K. Krishnan, Professor Kingsfield Goes to Delhi: American Academics, the Ford Foundation, and the Development of Legal Education in India, 46 AM. J. LEGAL HIST. 44748 (2004); Jayanth K. Krishnan, Academic SAILERS: The Ford Foundation and the Efforts to Shape Legal Education in Africa, 1957-1977, 52 AM. J. LEGAL HIST. 261, 289-91 (2012).

26. See DeZalay \& GARTH, supra note 21, at 81; Marion Fourcade, The Construction of a Global Profession: The Transnationalization of Economics, 112 AM. J. Soc. 145, 168-71 (2006); John Markoff \& Verónica Montecinos, The Ubiquitous Rise of Economists, $13 \mathrm{~J}$. PUB. POL'Y 37, 53-54 (1993).

27. See DEZALAY \& GARTH, supra note 21 , at 6.

28. Id.

29. Id at 198-219.

30. Id at 164-67. 
Organization, corporate governance, international commercial arbitration, and even international criminal law-bolstered the shift. Recently, "competitors" abroad seeking to imitate U.S. law schools have proliferated. In Europe, among many examples, we can count the first private law school in Germany, Bucerius, ${ }^{31}$ and the development of a legal education program at Sciences Po in Paris. In South America, relatively new private law schools include Torcuato di Tella in Buenos Aires and Fundacion Getulio Vargas in São Paulo and Rio de Janeiro. ${ }^{32}$ In Asia, the National Law Schools and the Jindal Global Law School in India, and the Peking School of Transnational Law in China, are especially notable examples of U.S. influence. The English, Canadian, and Australian law schools compete aggressively in this global market as well, seeking to attract the same LL.M. students who attend U.S. law schools. In one way, these and many other examples enhance the global market in legal expertise-including the central place of the elite U.S. law schools-by bringing U.S. scholarship and materials into the curriculum and by encouraging scholarship directed at an international audience. These and many other law schools, including many in Europe growing out of business schools, such as ESADE in Spain and Bocconi in Italy, both compete - offering courses and skills similar to what they might get from a U.S. LL.M. program-and reinforce the hierarchical global market in legal expertise. Not surprisingly, one measure of their success is their professors' ability to publish internationally, in the United States and Europe. ${ }^{33}$

The hierarchical global market that has recently emerged in law is also experienced in the lives of the LL.M. students. Lazarus-Black and Globokar downplay the "cash cow" aspect, but the authors do not contest the fact that the expansion of the programs has been revenue driven..$^{34}$ In fact, the incentive is double for the revenues from LL.M. tuition because these students' credentials do not count in U.S. News rankings. An ambitious dean will seek to minimize the JD class to keep JD standards as high as possible for U.S. News purposes and recoup that revenue from the LL.M. students who have no impact on rankings. The lack of impact also means that the LL.M. students do not command the merit-based scholarships central to buying relatively high-credentialed

31. Hariolf Wenzler \& Kasia Kwietniewska, Educating the Global Lawyer: The German Experience, 61 J. LEGAL EDUC. 462, 464 (2012).

32. Juny Montoya, The Current State of Legal Education Reform in Latin America: A Critical Appraisal, 59 J. LEGAL Educ. 545, 550 (2010).

33. To document the competition and the U.S. influence, one need only examine the web sites of the various law schools. One can easily find law and economics programs, programs in international business law, and many other examples of U.S. influence.

34. Lazarus-Black \& Globokar, supra note 12, at 26. 
students for U.S. News purposes. The potential lowering of standards for LL.M. students by multiplying their numbers also exacerbates the challenge for non-U.S. students trying to learn U.S. law, reinforcing the lower status of the foreign students.

The accreditation requirements clearly indicate the relative value of LL.M. programs. The ABA requires only that each program "will not detract from a law school's ability to maintain a sound JD degree program." 35 There are no quality standards. The interviews in the article suggest that the law school faculties generally see things the same way. Too many foreign students may undermine classroom discussion, slow the class learning, or take up precious office hours. Of course, program directors cherish the programs and do what they can, but the programs and the directors operate from a subordinate position. The U.S. News rankings are consistent. LL.M. credentials are not relevant to rankings, and LL.M. jobs do not count (and would hurt the rankings if they took the place of JD graduates). ${ }^{36}$ One of the Law School Survey of Student Engagement surveys confirms that the "regular" students do not have much interaction with the foreign students. The conclusion is quite striking:

Overall, JD students reported that their interaction with IGLSs [international graduate law students] was quite limited. For some students, even simple awareness of the presence of IGLSs in the law school community was unclear. Approximately one-third of JDs were uncertain whether there were IGLSs at their law school at all, despite each law school having a graduate program in which IGLSs were enrolled. ${ }^{37}$

There is an imperial logic in the fact that U.S. students and law professors have very little interest in learning from foreign students. They believe they have very little to learn and, on the other side, as Lazarus-Black and Globokar note, the foreign students have professed a lack of modern know-how in their own countries. ${ }^{38}$

35. AM. BAR Assoc., ABA Standards and Rules of Procedure for APProval of LAW SCHOOLS 2014-2015, at 23 Standard 313(c) (2014).

36. The U.S. News \& World Report only counts JD graduates, and therefore if LL.M. graduates took jobs and reduced the percentage of JD students hired, the rankings would potentially suffer.

37. LAW SCHOOL SURVEy OF STUdent Engagement, 2011 ANNuAl SuRVEy Results, NAVIGATING LaW School: PathS IN LEGal EduCation 14 (2011).

38. Lazarus-Black \& Globokar, supra note 12, at 37. 
A vignette from economics-where there is a parallel phenomenonillustrates this phenomenon. A Brazilian student some years ago made a striking comment about this process, referring to an economics student from Brazil at the University of Chicago. When the student is at the airport in São Paulo on the way to Chicago, the economics student noted, he is at the top of the hierarchy in Brazil. As soon as he lands in the United States, he goes right to the bottom of the U.S. hierarchy. If he needs extra money, he or his spouse may only take whatever jobs an undocumented person can take.

One hopes that U.S. law schools will do better in involving foreign graduate students in the life of the school, taking an interest in their insights and ideas and helping them succeed, but we have to recognize the structural factors that make such improvements difficult.

U.S. legal education, therefore, occupies a position analogous to what the Inns of Court meant to the British Empire and the Faculty of Law in Coimbra for the Portuguese Empire. This position at the top of the global hierarchy of legal expertise is not inevitable. It relates both to U.S. hegemony globally and to the strong role of law within the United States. The rise of China, for example, might one day encourage a flow of education and ideas on governance out of China, as happened in the past, although that is not happening today. ${ }^{39}$ More realistically, in the short term there is a global competition for tuition-paying Chinese students in law and in other fields, notably business. And if the Chinese decided that, say, the competing graduate programs in Australia or Singapore matched better with Chinese needs, the impact on the United States would be huge. The Chinese could in part redefine the hierarchy for a large portion of the market. So far, however, the U.S. position appears strong. ${ }^{40}$

The U.S. legal market position does not mean that only U.S. ideas and expertise count. Indeed, international stars who gain recognition in the United States already gain positions at top U.S. law schools. The market certainly absorbs from and changes in response to non-U.S. influences, but the U.S. legal academy is the global arbiter of what is the top in legal scholarship and practice. Indeed, the superiority of U.S. legal scholarship in the global market is taken for granted within the United States. It is indicative that we see articles on why, for example,

39. See David C. Kang, East Asia Before the West: Five Centuries of Trade and TRIBUTE 169-70 (2010).

40. Id. at 168-69 (noting that China has not yet invested in challenging the hegemony of Western and U.S. ideas). 
U.S. law and economics did not gain more influence quickly in Japanassuming the explanation must be pathology in Japan. ${ }^{41}$

The research in Lazarus-Black and Globokar's article on LL.M.s sheds some light on how this imperial process plays out today. One question raised by their article and by the imperial dynamic of the past is whether the LL.M. process reproduces hierarchy in home countries away from the United States-as seen in histories of colonial countries. We can interpret the research in this article in two ways. One is that the relative openness in the United States and the lack of elite status of many in these programs mean that the advantages of the LL.M. in the United States will produce upward mobility globally, rewarding those who through hard work and family sacrifice achieve the prized degree. There is no doubt truth to this interpretation.

However, we do not have comparable information on Harvard and its elite peers, and the very strong likelihood is that the law graduates who attend such schools come from a higher socioeconomic position. There is a parallel to the U.S. legal hierarchy (and indeed the hierarchy in most legal systems). With relatively few exceptions, those within the United States who attend elite law schools come from a substantially more privileged socioeconomic background than those who attend in the "lower tiers." 42 Nevertheless, the individuals who attend the non-elite schools as a strategy of upward mobility also rarely come from disadvantaged backgrounds. They are substantially more privileged than the U.S. population generally. ${ }^{43}$

We could imagine the same situation with LL.M.s. Those who attend the elite schools are highly likely to come from relatively elite backgrounds. I know that Harvard Law School used to and may still publish a directory of alumni that includes all the LL.M.s, and it was a remarkable point of entry into elites in the full range of global cities. The Harvard S.J.D. now appears to be at the top of Harvard's international hierarchy, but there are competitors within and outside of the United States-from Georgetown to Oxford's M.C.L., for example. Impressionistically, on the basis of who appears on graduate student panels at conferences, it also appears that many foreign law graduates with top credentials are getting U.S. PhDs in disciplines such as

41. See, e.g., J. Mark Ramseyer, Law \& Economics in Japan (Harvard John M. Olin Ctr. for Law, Econ., \& Bus., Discussion Paper No. 686, 2010), available at http://papers.ssm.com/sol3/papers.cfm?abstract_id=1767088 (explaining market imperfections that prevented Japan from adopting a "superior" approach).

42. RONIT DINOVITZER, ET AL., AFTER THE JD: FIRST RESUlts OF A NATIONAL STUdy OF LEGAL CAREERS 20 (2004), available at http://www.americanbarfoundation.org/ uploads/cms/documents/ajd.pdf.

43. Id. at 20-21 (showing how few children of non-college educated parents attend law school). 
sociology and economics. But I do not know of systematic research tracing the foreign graduates over time. I would expect a general division between elite and non-elite at least as strong as the one we see for U.S. students attending JD programs, but that is just a hypothesis.

Furthermore, those who are seeking upward mobility through LL.M.s from non-elite U.S. law schools may still be relatively privileged, despite the suggestion of some of the interviews. They need to know English, and they need to amass substantial sums of money, after all. We need to know more about their career trajectories. They may be very successful and gain upward mobility. But, as in their own domestic markets, their prospects are also not as strong as the elite law school graduates' are. As with respect to domestic JD students, there may be some overlap in careers, but the tracks are typically different. ${ }^{44}$

A further point about the privileged is in order. They have very easy access to LL.M. programs outside of the upper tier. The most important keys to entry at the schools in this study are twofold: English language skills and money. ${ }^{45}$ It also helps to have traveled internationally, which is another indication of privilege. It is not clear that entry into these programs is at all as meritocratic as domestic U.S. entry into the vast majority of U.S. law schools. Even if an LL.M. degree is helpful to the non-elite graduate, it looks like at least one role is to facilitate the reproduction of hierarchy abroad.

One of the insights of the article is that the international must be related to the national; this is true both inside and outside the United States. The research for the Lazarus-Black and Globokar article understandably does not detail that relationship. But as with respect to the Indian Brahmins and Parsi, the question is-how did they invest and use that foreign law degree within the Indian context to advance themselves? ${ }^{46}$ Lazarus-Black and Globokar's research cannot answer this question for students who have not graduated.

For what it is worth, mainly to start discussion, here are a series of potential ethnographic questions for LL.M. students. These are consistent with the focus in my work on career trajectories as the basis for understanding the structure of national legal fields and how they are changing. The answers-especially if only a few students are from a given country-would hardly be definitive, but might suggest lines for further inquiry. Questions might include: Which schools did you attend domestically? What kind of families did the student body of those schools come from? Where did those students generally go to college,

44. Id. at 44 (showing the percentage of elite graduates-highest among the most elite schools - who start at large corporate law firms).

45. Lazarus-Black \& Globokar, supra note 12, at 30.

46. For an excellent work on the Parsi, see SHARAFI, supra note 4. 
and what careers were preferred? What kinds of further study abroad or otherwise were students likely to pursue, and where would they likely go in terms of countries, schools, and programs? What would be the range of career options for those avenues of study? Where would advantaged students go, even if not to law? What paths did they choose if within law? What is the role of education abroad? What career tracks are available to which kinds of individuals with which kinds of credentials? I would expect somewhat different answers from different countries in Latin America, India, and China. ${ }^{47}$ Students, especially those aspiring for elite status from below, are often good sociologists, well aware of the hierarchies and trajectories particularly of peers who are more advantaged than they are. The insights of these interviews would only be the basis for some hypotheses, but they might provide a starting point for more systematic inquiry.

Much better would be qualitative and quantitative research tracking LL.M. graduates and situating them in their local and international contexts. ${ }^{48}$ Particularly in elite schools, even if the U.S. students almost invariably neglect building relationships with the foreign students, there is evidence that relationships built abroad lead to later alliances and mutual support. Lee Kuan Yew's autobiography makes clear how important the contacts he made studying law at Cambridge were for his political career ${ }^{49}$ An autobiography of one of the Philippine political leaders against Marcos noted the importance even of Philippine contacts that he made at Yale Law School. ${ }^{50}$ Three of the leading economists of the neoliberal revolution in Latin America met and became friends studying abroad in Cambridge at Harvard and MIT. ${ }^{51}$ Specifically within the sphere of U.S. elite law, Yale's Seminar in Latin America on Constitutional and Political Theory ${ }^{52}$ has generated a strong network of scholars within Latin America who evidently

47. Since my research on globalization and law does not extend to Africa and the Middle East, I do not venture to discuss these regions here, but clearly Africa has become a larger part of the LL.M. market recently.

48. See generally Carole Silver, States Side Story: Career Paths of International LL.M. Students, or "I like to be in America," 80 FORDHAM L. REV. 2383 (2012) (discussing empirical data that tracks careers of international law graduates who earned an LL.M. in the United States).

49. See Lee KuAN Yew, The Singapore Story: Memotrs of LeE KuAN Yew 99 (1998).

50. Jovito R. Salonga, Journey of Struggle \& Hope: The Memoir of Jovito R. SALONGA (2001).

51. DEZALAY \& GARTH, supra note 21 , at 121.

52. Program for SELA 2014, YALE LAW SCH. (May 15, 2014), http://www.law.yale.edu/ intellectuallife/18360.htm. 
reinforce each other's research and career trajectories.53 In these contexts, people of relative privilege with good connections reinforce each other's place on a fast track to national and international importance.

The great virtue of Lazarus-Black and Globokar's research is that it recognizes the importance of the LL.M. programs, which, as my Comment suggests, are not deemed worthy of much scholarly investment by mainstream U.S. legal academia, with very few exceptions (most notably Carole Silver). ${ }^{54}$ Their article also goes further, looking at students who are not just the top of the LL.M. group, but focuses on those who attend non-elite law schools-a group to date almost completely neglected but who are an important part of the story. I believe that their research can be situated in a context connected more closely to international political economy, but as I have suggested in this article, the main point is that their research opens up important lines of inquiry that I hope they and others will pursue.

53. See History of SELA, YALE LAW SCH., http://www.law.yale.edu/intellectuallife/ selahistory.htm (last visited Nov. 7, 2014), for the history of SELA and its relatively cohesive network.

54. See, e.g., Silver, supra note 48. 